\title{
GNG11 wt Allele
}

National Cancer Institute

\section{Source}

National Cancer Institute. GNG11 wt Allele. NCI Thesaurus. Code C114332.

Human GNG11 wild-type allele is located in the vicinity of 7q21 and is approximately $5 \mathrm{~kb}$ in length. This allele, which encodes guanine nucleotide-binding protein $G(I) / G(S) / G(O)$ subunit gamma-11 protein, plays a role in the mediation of $\mathrm{G}$ protein-dependent signaling. 